\title{
Palynology of the Kazanian stratotype section (Permian, Russia): palaeoenvironmental and palaeoclimatic implications
}

\author{
Annette E. Götz ${ }^{1,2}$ and Vladimir V. Silantiev ${ }^{2}$ \\ ${ }^{1}$ University of Pretoria, Department of Geology, Private Bag X20, Hatfield, 0028 Pretoria, South \\ Africa, Email: annette.goetz@up.ac.za \\ 2Kazan Federal University, 18 Kremlyovskaya St., Kazan 420008, Republic of Tatarstan, Russian \\ Federation, Email: Vladimir.Silantiev@kpfu.ru
}

\begin{abstract}
Palynomorph assemblages reflect changes in land plant communities and are thus significant proxies to interpret palaeoenvironmental and palaeoclimatic changes. The Middle Permian of the East European Platform is crucial to the understanding of marine and non-marine palaeoclimate archives and interregional correlations of marine and non-marine successions, utilizing palaeoclimate signatures documented in the palynological record. New palynological data from the Kazanian stratotype section are presented and interpreted with respect to palaeoenvironment and palaeoclimate. This dataset will serve as a basis for ongoing studies on the type area of the Kazanian and the midPermian biodiversity patterns, preceding the end-Guadalupian crisis and the changes of the endPermian biotic diversification followed by the most severe extinction event in Earth's history at the Permian-Triassic boundary.
\end{abstract}

Keywords Palaeoenvironment, Palaeoclimate, Palynology, Permian, Russia

\section{Introduction}

The East European Platform is a type region for the Permian system. One of the largest Permian sedimentary basins in the world (named after the Perm province of Russia; later in $1841 \mathrm{R}$. Murchison introduced this name for the geological system Permian) is located in this area. The Permian deposits cover stratigraphically a continuous succession representing more than 45 Ma of Earth’s history. The marine part of the succession comprises the Cisuralian Series consisting of the Asselian, Sakmarian, Artinskian, and Kungurian stages. The marine-continental transition is documented by the Ufimian, Kazanian, and Urzhumian regional stages, the former representing the uppermost part of the Cisuralian (and Kungurian) and the two last ones constituting the Biarmian regional Series (= Guadalupian). 

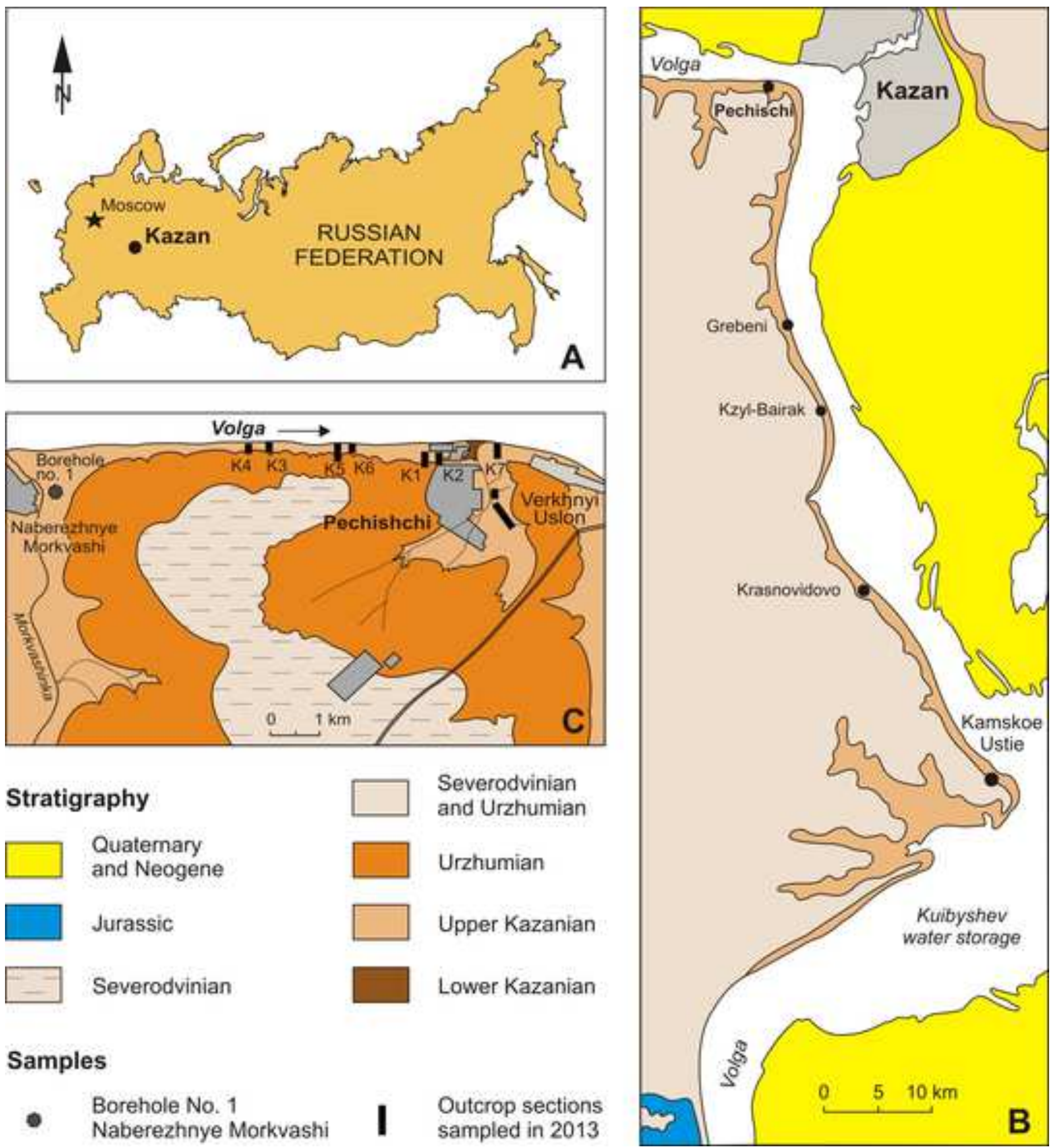

\section{Stratigraphy}

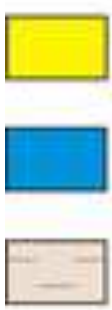

Quaternary

and Neogene

Jurassic

Severodvinian
Severodvinian and Urzhumian

Urzhumian

Upper Kazanian

Lower Kazanian

\section{Samples}
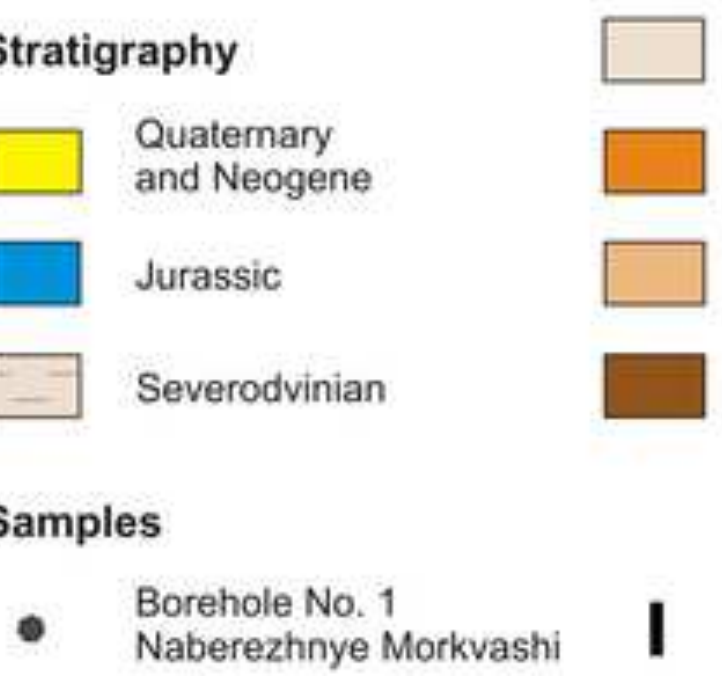

Lower Kazanian
Figure 1. Study area (A - general map of the Russian Federation showing the type area of the stage situated near the town of Kazan; B generalized geological map of the Volga-Kama region near the town of Kazan, Republic of Tatarstan) and location of the Pechishchi outcrop sections (K1-K7) sampled in 2013 and borehole No. 1 Naberezhnye Morkvashi (C). 
Continental deposits represent the Tatarian regional Series (= Lopingian) including the Severodvinian and Vyatkian regional stages.

Marine-continental (transitional) and continental formations are the most difficult to interpret in terms of palaeoenvironment and palaeoclimate due to the lack of reliable stratigraphic (biotic and abiotic) markers for interregional correlations. However, these formations (marine-continental and continental) cover a large part of the East European Platform (about 3 million $\mathrm{km}^{2}$ ) and range in thickness from 100 to $400 \mathrm{~m}$ on the Platform, increasing to 600-1500 $\mathrm{m}$ in the north-south-trending foredeep along the western margin of the Ural Mountains. These formations were formed in different facies zones under semiarid to subhumid climate conditions. The marine part of the marine-continental formation contains a low diversity marine fauna of forams, corals, brachiopods, bivalves, bryozoans (Solodukho et al. 1993), and conodonts (Chalimbadja and Silantiev 1997; Chernykh et al. 2001). Continental beds are rich in fossil remains of all biostratigraphically significant non-marine groups: plants, including palynomorphs and charophytes, ostracods, conchostracans, insects, bivalves, gastropods, fishes, and tetrapods (Esaulova et al. 1998; Golubev 2000). Today these deposits are well exposed in many outcrops due to a high relief (up to 300 m) and ongoing mining activities.

The present study aims to interpret palaeoenvironment and palaeoclimate by palynomorph assemblages from the Kazanian stratotype section (Fig. 1), representing a mid-Permian age, a period of major changes in land plant communities documented in the palynological record.

\section{Geological setting}

\section{Palaeogeography}

During Kazanian times, the eastern part of the East European Platform was covered by an elongated, bayshaped marine basin (600-1200 x $3000 \mathrm{~km}$ ) connected with the Boreal Ocean in the Northwest. The bay shows a south-east to north-west extension and was located approximately between $15^{\circ}$ and $40^{\circ}$ north latitude (Fig. 2), in arid and semiarid climate zones in the south and humid to sub-humid climate zones in the north. A desert plain composed of eroded sulfate and carbonate (Carboniferous and Early Permian rocks, "White desert") adjoined the bay from the southwest. The northeast coast of the bay was characterized by foothill lowlands (with a width of 50 to $500 \mathrm{~km}$ ) with numerous lakes, which were recharged through rivers draining from the Ural Mountains into the foreland. The mountain slopes were covered by a red-coloured weathering crust whose materials were transported in large volumes by rivers to the plain. This process led to the formation of thick red-coloured continental successions containing lacustrine, alluvial and soil deposits. Thus, during Kazanian times, two different but connected 


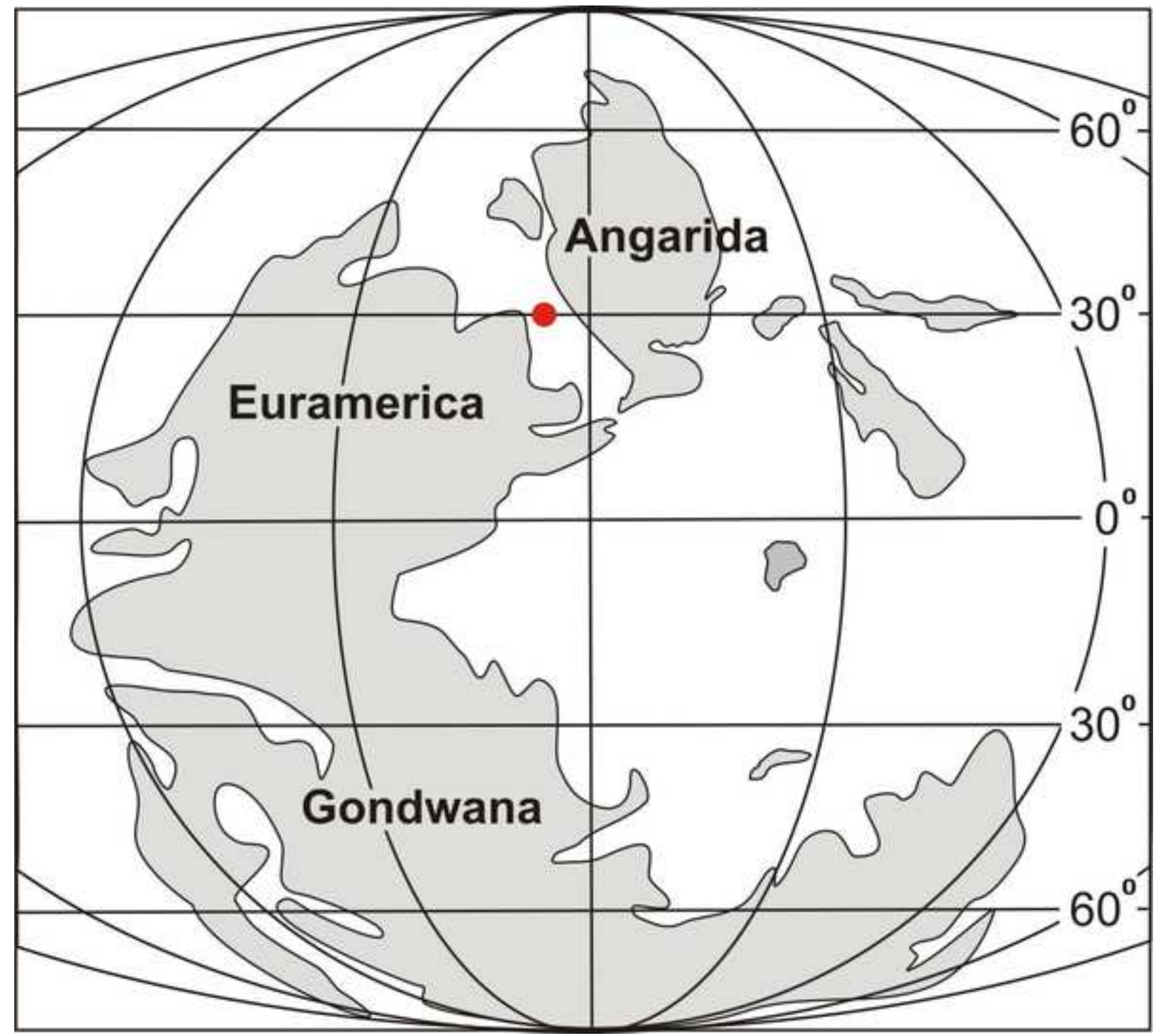

Figure 2. Palaeogeography and position of the studied Pechishchi section. Palaeogeographical reconstruction of the Middle Permian modified after Ziegler et al. (1997) 
sedimentary basins are located within the East European Platform: a marine and continental basin, each characterized by distinct biota.

\section{Stratigraphy}

The International Stratigraphic (Chronostratigraphic) Scale (ISC) follows the concept of stratotype sections and their global stage boundaries (GSSP - Global Stratotype Section and Point Boundary), marked by the first occurrence of zonal index species in continuous phylogenetic lines with additional palaeomagnetic, geochronological and isotopic markers. In this scale, the Permian system is divided into three Series: Cisuralian, Guadalupian and Lopingian (Fig. 3). The Cisuralian consists of Russian stages: Asselian, Sakmarian, Artinskian and Kungurian. The Guadalupian is subdivided by stages of North America, the Lopingian by stages of South China. Their boundaries are defined by the First Appearance Datum (FAD) of index conodont species in a single phyletic line (Shen et al. 2013).

The general stratigraphic scale of the Permian system of Russia has been significantly revised and modified in recent years. It is based on a modified regional scale of the East European Platform, which also includes three Series (Fig. 3) but remains still substantially different from the ISC (Stratigraphic Code of Russia 2006). The differences include the stratigraphic range of the Middle and Late Series, the grouping of stages within these series and their naming (Fig. 3).

The Middle Permian of the regional scale of the East European Platform is defined as Biarmian Series divided into the Kazanian and Urzhumian stages. The Late Permian is represented by the Tatarian Series, which consists of the Severodvinian and Vyatkian stages. The lower boundaries of the stages, formed by continental red beds (Urzhumian, Severodvinian, Vyatkian), are marked by the first occurrence of nonmarine ostracod species in continuous phylogenetic lines (Kotlyar et al. 2013). The boundary between the Middle and Late Permian Series in the regional scale of the East European Platform does not coincide with the boundary between the Middle and Late Permian Series in the ISC. At a regional scale of the East European Platform this boundary is defined on one stage below (Fig. 3). The lower boundary of the Kazanian stage and Biarmian Series is defined by the first occurrence of the age-diagnostic conodont Kamagnathus khalimbadzhae. This FAD was already detected in many localities of the East European Platform (Chernykh et al. 2001). A Roadian assemblage of ammonoids containing Sverdrupites harkeri, Sv. amundseni, Biarmiceras esaulovae, B. kremeshkense, B. barskovi, Medlicottia sp., Daubichites sp. appears in the section slightly above the lower boundary of the Kazanian, representing an additional biostratigraphic marker (Leonova 2007). 


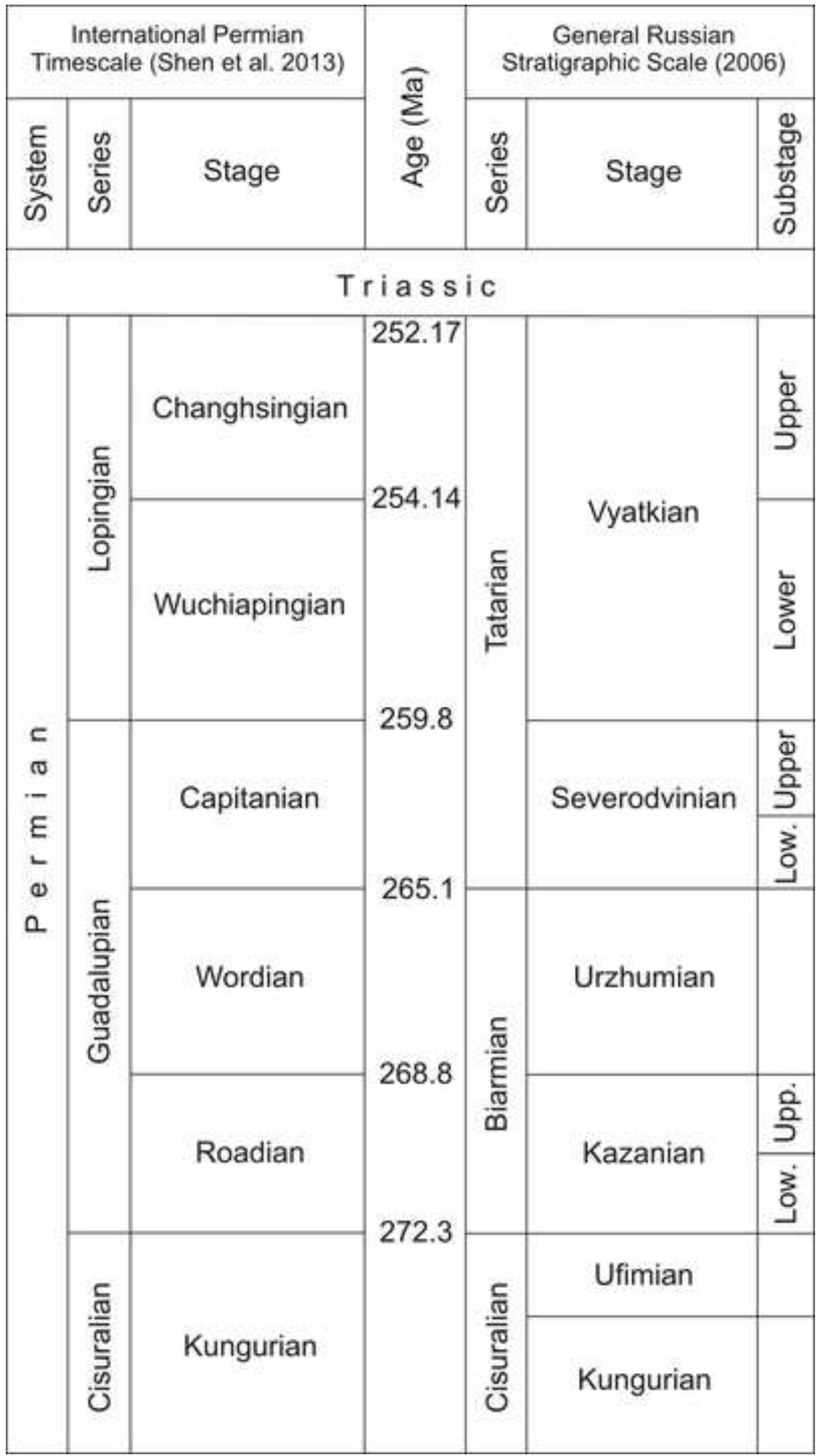

Figure 3. Stratigraphy of the study area in relation to the International Permian timescale (modified after Kotlyar et al. 2013). 
However, in the stratotype region the lower boundary of the Kazanian stage may not be clearly defined, because marine Kazanian successions overly either the Sakmarian dolomites (with a clearly defined hiatus) or the continental red beds (probably with a hiatus); and thus, the boundary can be determined much lower in stratigraphy.

The Kazanian stage is traditionally subdivided into two substages (Fig. 3). The boundary between the substages is at the base of the "Yadrenyi Kamen" Member in the Pechishchi section (Tatarstan Republic). The boundary is considered as facies dependent due to its poor biostratigraphic determination. It is difficult to trace this boundary even within the East European Platform and in different sections it may be determined at various stratigraphic levels.

\section{Pechishchi section}

The type area of the Kazanian (Solodukho et al. 1993) is located near the town of Kazan in the VolgaKama region, Republic of Tatarstan, Russian Federation (Fig. 1). The Kazanian reaches a thickness of up to 100-200 m, with marine carbonates (limestones, dolomites) in the west-southwest and a progressive change from grey-coloured marine and lagoonal deposits (limestone, dolomite, marlstone with siltstone and gypsum intercalations) to continental red-coloured deposits (siltstone, claystone, marlstone, sandstone alternations) towards the east-northeast. The Pechishchi section (figs. 4, 5) exposes the latest Early Kazanian (marine limestones) and entire Late Kazanian (Prikazanskie and Pechishchinskie beds: dolomites, marlstones; Verkhneuslonskie and Morkvashinskie beds: dolomitic breccias, oolitic dolomites, siltstones).

\section{Materials and methods}

Palynological samples from the Kazanian stratotype section near the village of Pechishchi, comprising the latest Early Kazanian and entire Late Kazanian substages, were analysed with respect to palynostratigraphy and palaeoenvironmental and palaeoclimatic changes recorded in palynomorph assemblages. For palynological analysis 10 samples (one from the latest Early Kazanian and nine from the Late Kazanian) were prepared using standard palynological processing techniques, including $\mathrm{HCl}$ $(33 \%)$ and $\mathrm{HF}(73 \%)$ treatment for dissolution of carbonates and silicates, and saturated $\mathrm{ZnCl}_{2}$ solution $(D \approx 2.2 \mathrm{~g} / \mathrm{ml})$ for density separation. Residues were sieved at $15 \mu \mathrm{m}$ mesh size. Slides have been mounted in Eukitt, a commercial, resin-based mounting medium.

Sedimentary organic matter is grouped into phytoclasts, sporomorphs, phytoplankton and degraded organic matter. The relative percentage of these components is based on counting at least 300 particles 


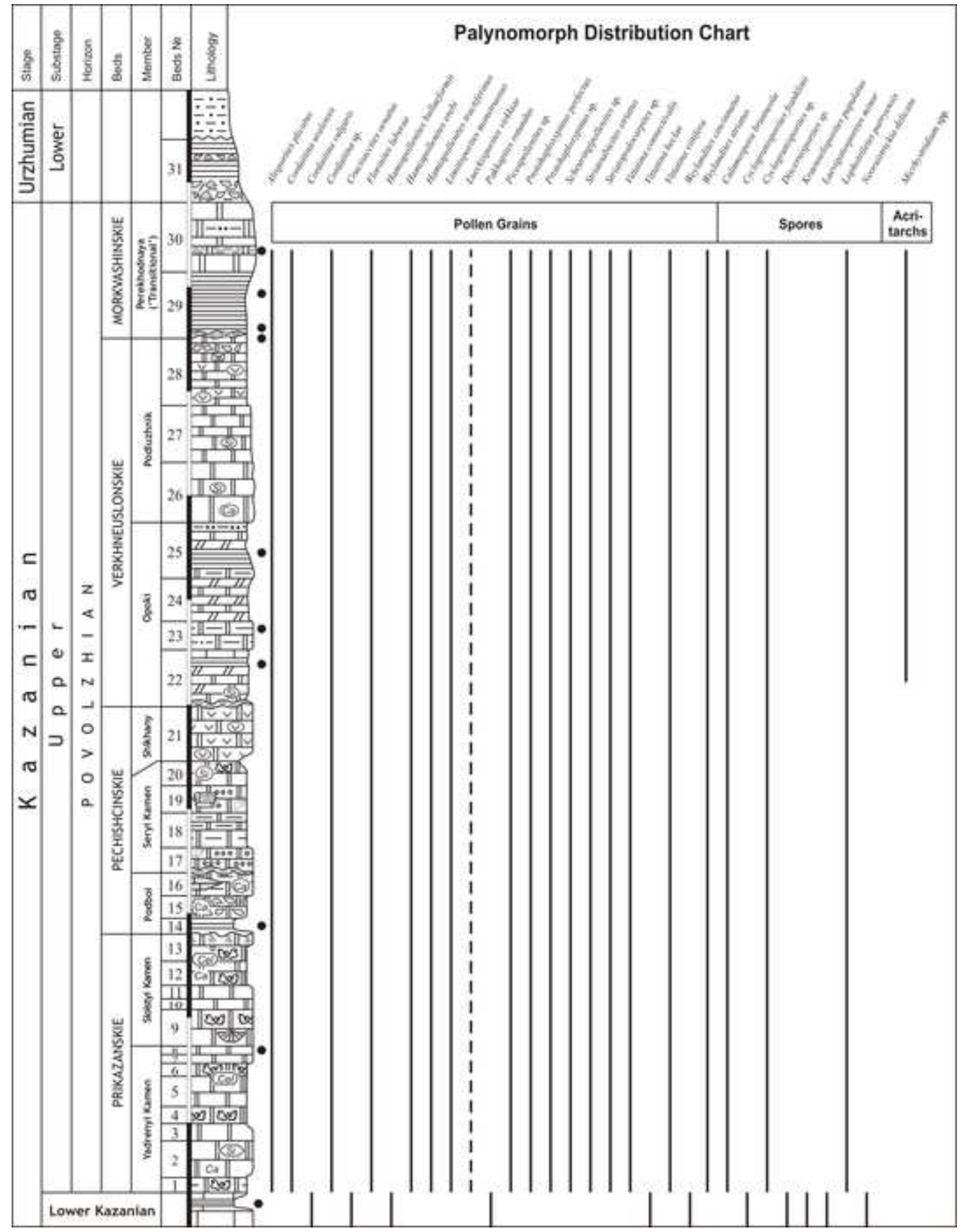

Figure 4. Palynomorph distribution chart of the Pechishchi section. The total thickness of the studied interval is about $50 \mathrm{~m}$, scale bars 5 $\mathrm{m}$ each. Sample horizons are marked by black dots. 


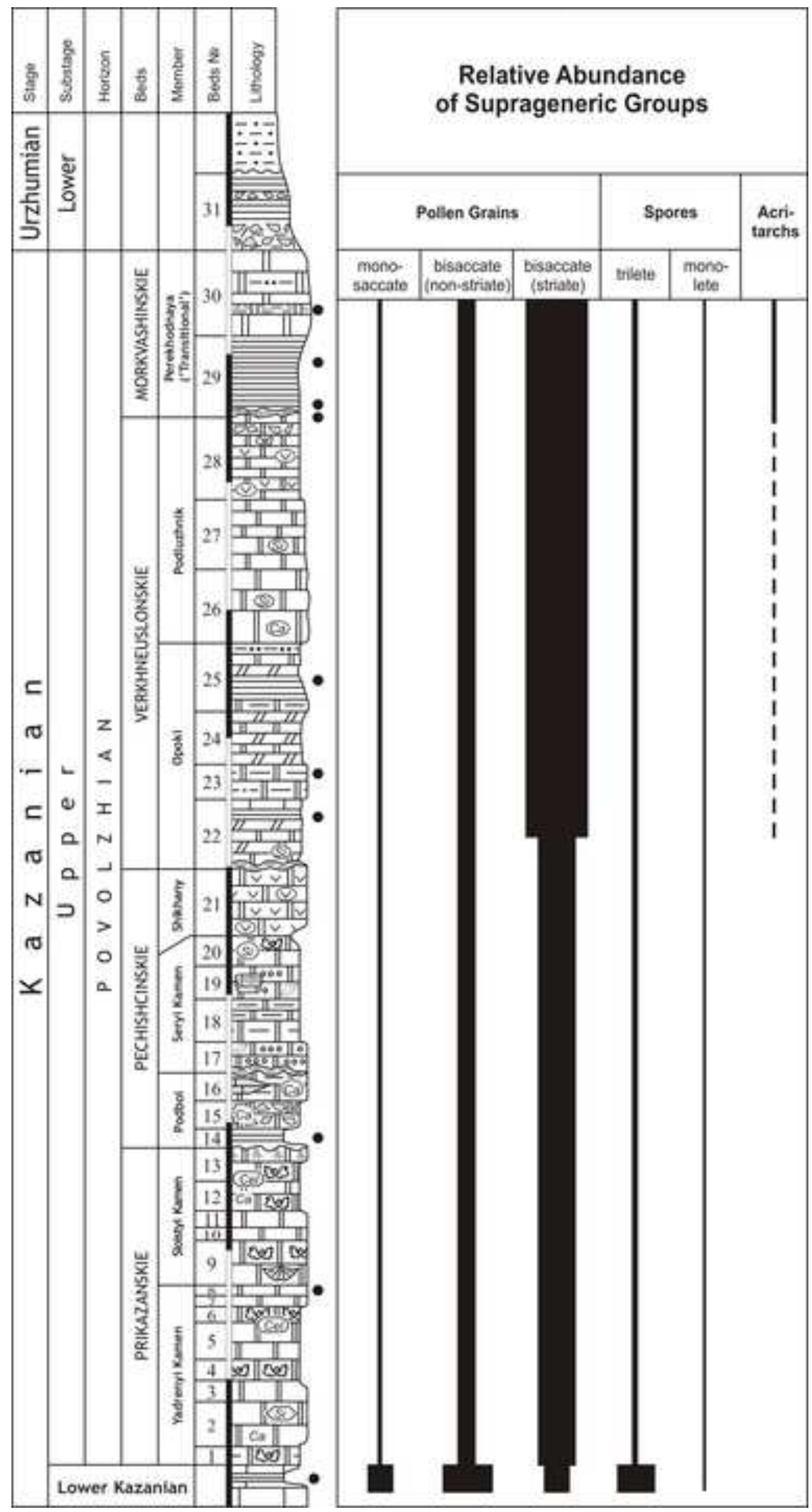

Figure 5. Relative abundance of suprageneric groups (pollen, spores, acritarchs) based on counts of 200 specimens. The total thickness of the studied interval is about $50 \mathrm{~m}$, scale bars $5 \mathrm{~m}$ each. Sample horizons are marked by black dots. 
per slide. The relative abundance of suprageneric groups (pollen, spores, acritarchs) is based on counts of 200 specimens per slide.

\section{Palaeoenvironment, palaeoclimate and depositional model}

The study area is part of the eastern flank of the Kazan Sea and the entire Kazan Sea area is subdivided into seven distinct depositional environments from the West to the East (Forsh 1955; Golubev 2001; Silantiev 2001) (Fig. 6). The studied Pechishchi section represents the depositional areas 2, 3, and 4. Terrestrial palynomorphs were mainly transported from the eastern hinterland (depositional area 7) by wind (pollen grains) and by river and delta systems into the adjacent lagoonal and open marine settings. Marine phytoplankton (acritarchs) is characteristic of restricted (lagoonal) and open marine settings. Palynofacies is dominated by terrestrial particles (pollen grains, spores) including phytoclasts of different size and shape, and different preservation states (opaque, translucent). The high amount of phytoclasts indicates a lush vegetation of the eastern hinterland.

1. West Bank of the Kazan Sea. A flat, plateau-like area formed by Carboniferous and Early Permian carbonate rocks ("White desert"). This area is characterized by intense erosion due to weathering. The climate was hot and dry (arid). There was hardly river systems developed. Minor soilforming processes and only sparse vegetation are assumed. Faunal elements are rare, only small vertebrates were present by lizard-like forms.

2. Hypersaline, protected lagoons. The influx of freshwater and terrigenous material from the western shore of the Kazan Sea was strongly limited. The salinity of the water in the lagoons was periodically increased. During these times, gypsum and salt were accumulated. The climate was hot and fairly dry (arid). Faunal elements are rarely present by microbial bioherms. The characteristic lithologies are wavy-bedded limestones interbedded by gypsum and rock salt.

3. Bioherms and reefs. Large reefal bodies formed by bryozoans, crinoids, corals and brachiopods. In places these build-ups raised above the sea surface and built the ridges separating the lagoons with increased salinity from the open ocean. It is assumed that the islands were covered with sparse vegetation. Faunal elements include ammonites, conodonts, and fishes (sharks teeth and spines).

4. Open Sea. A very narrow zone with predominantly carbonate sedimentation. The dominant lithologies are limestones and secondary dolomites. A high degree of bioturbation points to an oxic environment with diverse benthic biota.

5. Bars and barrier islands. These large ribbon-like sand bodies were elongated parallel to the coast, separating the open sea from the brackish lagoons. Due to humid climate conditions, the vegetation 


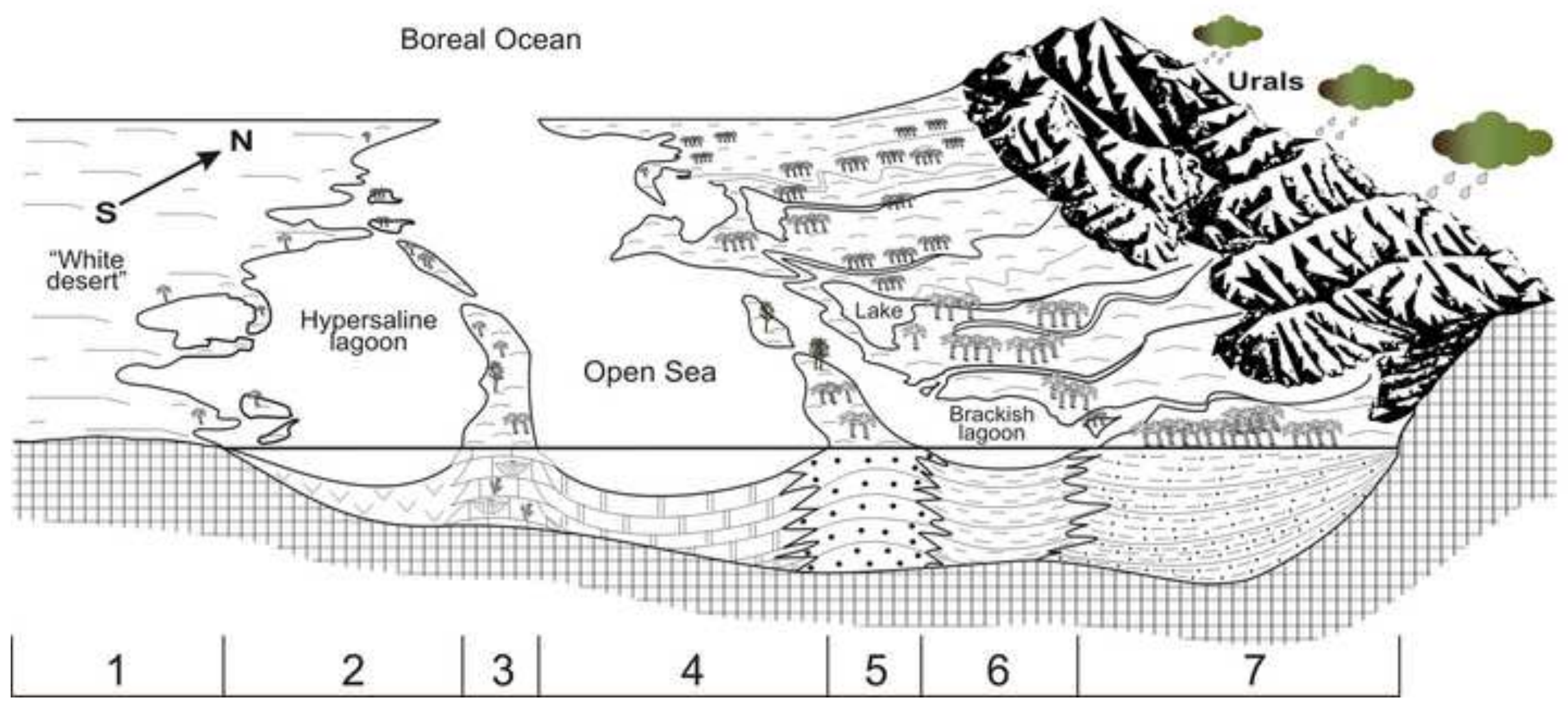




\section{$\div \div \div \div$ siltstones}

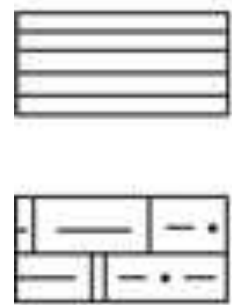

clays

argillaceous lime-

stones and dolomites

oolitic limestones

and dolomites

dolomitic breccia
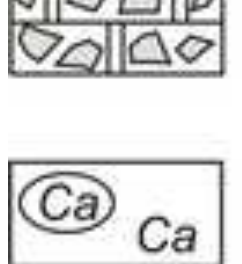
carbonaceous rocks

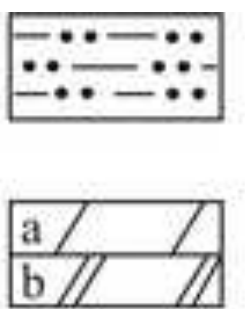

siltstones and

sandstones

marls (a),

dolomitic marls (b)

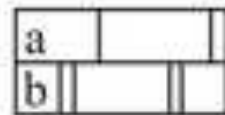

limestones (a)

and dolomites (b)

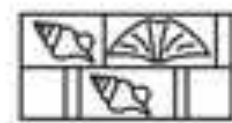

organogenic and detrital

limestones and dolomites

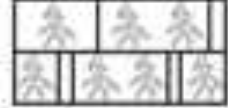

plant roots in situ in limestones and dolomites

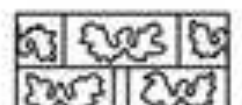

cavernous limestones and dolomites

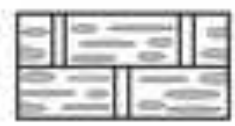

dolomitic conglomerate

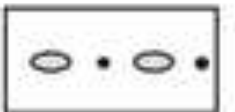

pebbles and gravel

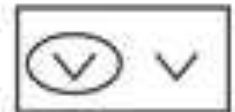

lenses of gypsum, gypsiferous rocks

carbonate concretions,

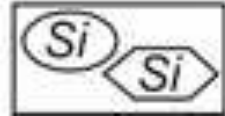

flint concretions, crystalline quartz

\section{(Cel celestine}

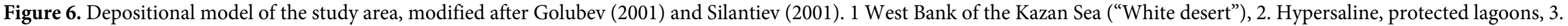
Bioherms and reef buildups, 4. Open Sea, 5. Bars and barrier islands, 6. Brackish lagoons and deltas, 7. Alluvial-lacustrine plains. 
is diverse and lush. Invertebrates include various shallow-water forms of brachiopods and bivalves. The dominant lithologies are sandstones with wave ripple marks and oolitic limestones; the latter characterize the transitional zone from sand bars to the open sea.

6. Brackish lagoons and deltas. Deltaic successions contain deposits of copper ore (copper sandstones), coal and bitumen. Floral and faunal elements are similar to those known from the alluvial plains. Lagoons were characterized by varying desalination. In some lagoons, clay and organic-rich sediments were accumulated; other lagoons contain mainly carbonate sediment. This zone represents a low-energy depositional environment, partially or completely isolated from the open sea by sand bars and spits. Stagnant conditions periodically arose in these shallow basins. Predominant lithologies are limestones with fine horizontal lamination, clays with thin layering, and numerous thin seams of coal. Limestones are often bituminous in varying degrees; coquinas are common. Faunal elements include euryhaline invertebrates (bivalves, gastropods, serpulids), insects, numerous fish (often complete skeletons) and exclusively aquatic tetrapods (amphibians).

\section{Alluvial-lacustrine plains forming the east bank of the Kazanian Sea. Vast lowland} characterized by a perfectly aligned relief gradually rising towards the Urals. The climate is sub-humid and probably seasonal.

This is an important feature of the east bank and different from the west bank zone. Climatic differences between the east and west banks determine the asymmetric facial profile of the Kazanian Sea: a large amount of terrigenous sediments, sand bars, lagoons rich in organic matter, marshes and swamps, diverse and abundant terrestrial floral and faunal elements in the East; bioherms, saline lagoons, terrestrial environments with sparse vegetation in the West. Due to the high humidity, the eastern area was characterized by lush vegetation. Localities of fossil flora (including wood fragments in fluvial sandstones) are known from deposits which had been formed in lakes, oxbow lakes, floodplains and river channels. Fossil invertebrates (ostracods, conchostracans, non-marine bivalves) are abundant. Also, localities of fish and terrestrial vertebrates (amphibians and therapsids) are known in many places representing this eastern area, dominated by cross-bedded sandstones, sandstones with ripple marks, fluvial conglomerates, and paleosoils (Esaulova et al. 1998).

\section{Palynology}

\section{Palynostratigraphy}

A high-resolution palynostratigraphic framework of the Permian stages in the Ural Mountains is seen as crucial to establish and refine global (marine - non-marine) correlations and becomes a focus within 
recent studies on the type sections. The Early Permian stages (Asselian, Sakmarian, Artinskian, and Kungurian) are biostratigraphically well dated based on the occurrence of diverse marine (invertebrate) faunas, whereas the dating of the partly terrestrial and partly marine Permian stages (Ufimian, Kazanian, Severodvinian and Vyatkian) is still in progress and hampered due to only non-marine and sparse marine faunas (Kotlyar et al. 2013).

Thus, palynological studies are very important to establish a biostratigraphic scheme to be applied in both marine and non-marine depositional environments. Previous works include palynological data for the Permian of European Russia (Bogov 1971; Varyukhina 1971; Molin and Koloda 1972; Chuvashov and Dyupina 1973; Faddeyeva 1974; Gayazova 1974; Varyukhina et al. 1975; Virbitskas 1983; Gomankov 1992), providing the general stratigraphic ranges of identified taxa without proposing range zones for interregional correlation. On the other hand, comparisons of the Permian assemblages from Russia with those from other parts of the world remain difficult, due to the different taxonomic treatment adopted by the different palynologist "schools". Utting et al. (1997) addressed this point in the most recent publication on the palynology of Permian type sections in Russia. These authors also discussed the differences between palynomorph assemblages from Middle Permian stages of Russia and those of the Canadian Arctic and other circumpolar regions (southern Barents Sea, Mangerud 1994; Greenland, Balme 1980), hindering interregional correlation. It was concluded that the recognized differences are most likely the result of variations in the parent flora related to different palaeoclimatic conditions.

In the present study we focus on the Kazanian stage with new palynological data from the latest Early Kazanian and entire Late Kazanian (Povolzhian), exposed in a section near the village of Pechishchi (Fig. 1). The palynomorph assemblage is dominated by pollen grains and a major change in composition occurs at the Lower-Upper Kazanian substage boundary with the last occurrence of Cordaitina spp., Crucisaccites ornatus, Hamiapollenites bullaeformis, Pakhapites rotundus, Vittatina heclae, and Weylandites cincinnatus as well as the last occurrence of the spores Cyclogranisporites franklinii, Discernisporites sp., Kraeuselisporites papulatus, and Neoraistrickia delicata (Fig. 4). The pollen grains Alisporites plicatus, Cordaitina uralensis, Florinites luberae, Hamiapollenites erebi, Hamiapollenites tractiferinus, Limitisporites monstruosus, Lueckisporites virkkiae, Piceapollenites sp., Protohaploxypinus spp., Scheuringipollenites sp., Striatoabieites striatus, Striatopodocarpites sp., Vittatina connectivalis, Vittatina vittifera, and Weylandites striatus as well as the spores Calamospora brunneola and Lophotriletes parryensis first occur in the Late Kazanian. Marine phytoplankton (Micrhystridium spp.) is only present in the upper part of the Late Kazanian. 
Makarova (2007) studied palynological assemblages from a borehole (No. 1 Naberezhnye Morkvashi; Fig. 1) and an outcrop section close to the village of Pechishchi and described four assemblages (assemblage 1 and 2 indicating an Early Kazanian age, assemblage 3 and 4 indicating a Late Kazanian age). This dataset shows a general dominance of bisaccate, striate pollen grains and an increase of this pollen group is observed upsection. Spores are rare elements in the entire succession.

\section{Palaeoenvironmental and palaeoclimatic implications}

The palynomorph assemblages studied show a very striking trend within the section (Fig. 5): the lower part is dominated by trilete spores and monosaccate and bisaccate, non-striate pollen grains. The upper part of the section clearly shows the increase of bisaccate, striate pollen grains dominating the assemblage in the uppermost part. The dominance of bisaccate, striate pollen grains and an increase within the Kazanian was also reported by Makarova (2007).

Different relative abundances of sporomorphs indicate changes in the upland and lowland vegetation related to changes in the palaeoenvironment, e.g. development of lake and river systems, moving of the shoreline, uplift in the hinterland, as also documented in the sedimentological record. Besides these palaeoenvironmental (short-term) changes recognized, a long-term trend is interpreted in terms of climate change from a warm temperate to a warm dry climate. This change is documented in the sedimentological record by e.g. an increase of gypsiferous dolomites upsection and it is also reflected in geochemical signatures (Larochkina and Silantiev 2007). The palynological data show this climatic signal by the change of a fern and horsetail lowland community and an upland conifer community dominated by monosaccate-producers to a gymnospermous flora of striate bisaccate-producers. Such changes inferred from palynomorph assemblages, reflecting the vegetation of a specific area, are recently detected in many other Permian and Triassic settings (e.g., Ruckwied et al. 2008; Götz et al. 2011; Götz et al. 2013; Götz and Ruckwied 2014) and climatic signals recorded in palynomorph assemblages have been recently also successfully applied to cross basin correlation (Ruckwied et al. 2014). The new palynological data from the Kazanian stratotype section show the potential to perform high resolution palaeoclimatic reconstructions based on changes in the palynomorph assemblages.

\section{Conclusions}

The new palynological data presented herein provide a basis for marine - non-marine correlations within the partially marine and partially terrestrial deposits of the Middle Permian Kazanian stage of the East European Platform. Stratigraphical changes in the palynomorph assemblages reflect regional short-term 
changes in palaeoenvironment as well as palaeoclimatic changes of interregional importance. Thus, palynological data enable for interregional correlations of marine and non-marine settings on high time resolution, utilizing palaeoclimatic signatures. Ongoing studies focus on the correlation of Permian depositional series of the East European Platform based on palaeoclimate signatures recorded in palynomorph assemblages.

\section{Acknowledgments}

The work is performed according to the Russian Government Program of Competitive Growth of Kazan Federal University. We kindly acknowledge the constructive comments of Jörg W. Schneider (TU Bergakademie Freiberg) and Katrin Ruckwied (Shell International Exploration and Production, Houston).

\section{References}

Balme BE (1980) Palynology of Permian-Triassic boundary beds at Kap Stosch, East Greenland. Meddelelser om Grønland, 200(6).

Bogov AV (1971) Stratigraphic significance of the spore and pollen assemblages in the Permian deposits of the Tatar ASSR. In: Ignatyev VI (ed) Geology of the Volga and Kama regions. Kazan University Press, Kazan, USSR, pp. 157-164. (in Russian)

Chalimbadja VG, Silantiev VV (1997) Conodonts from the Upper Permian type strata of European Russia. Proceedings of the Royal Society of Victoria 110 (1/2):137-145.

Chernykh VV, Chalimbadja VG, Silantiev VV (2001) Representatives of the Kamagnathus gen. nov. (conodonts) from Kazanian Stage of Volga region. Ekaterinburg: Institut Geologii i Geokhimii, Collected articles 6:74-82. (in Russian)

Chuvashov BI, Dyupina GV (1973) Upper Palaeozoic terrigenous deposits of western slope of Middle Urals. Trudy Institute Geologii i Geokhimii Sverdlovsk 105:3-208. (in Russian) 
Esaulova NK, Lozovsky VR, Rozanov AYu (eds.) (1998) Stratotypes and reference sections of the Upper Permian in the regions of the Volga and Kama Rivers. Moscow: GEOS, 300 p.

Faddeyeva IZ (1974) Palynological characteristics of the stratotypes of the Permian stages in the USSR. In: Palynology of the Proterophytic and the Paleophytic. Proceedings of the $3^{\text {rd }}$ International Palynological Conference, Nauka, Moscow, USSR, pp. 135-139.

Forsh NN (1955) The Permian Deposits. The Ufa Formation and the Kazanian Stage. Trudy Vsesoyuznogo nauchno-issledovatelskogo Instituta, Novaya Seria 92:1-156. (in Russian)

Gayazova AK (1974) Spore-pollen assemblages of the lower Kazanian deposits of the western part of the Orenburg oblast. In: Palynology of the Proterophytic and the Paleophytic. Proceedings of the $3^{\text {rd }}$ International Palynological Conference, Nauka, Moscow, USSR, pp. 160-165.

Golubev VK (2000) The faunal assemblages of Permian terrestrial vertebrates from Eastern Europe. Paleontological Journal 34(2):211-224.

Golubev VK (2001) Event Stratigraphy and Correlation of Kazanian Marine Deposits in the Stratotype Area. Stratigraphy and Geological Correlation 01/2001, 9(5):454-472.

Gomankov AV (1992) The interregional correlation of the Tatarian and the problem of the Permian upper boundary. International Geology Review 34:1015-1020.

Götz AE, Ruckwied K (2014) Palynological records of the Early Permian postglacial climate amelioration (Karoo Basin, South Africa). Palaeobio Palaeoenv 94(2):229-235.

Götz AE, Ruckwied K, Barbacka M (2011) Reconstruction of Late Triassic (Rhaetian) and Early Jurassic (Hettangian) palaeoecology and palaeoenvironment of the Mecsek Coal Formation (S Hungary): implications from macro- and microfloral assemblages. Palaeobio Palaeoenv 91(2):75-88.

Kotlyar GV, Golubev VK, Silantiev VV (2013) General stratigraphic scale of the Permian system: current state of affairs. In: Zakharov VA (ed.) General stratigraphic scale of Russia. Moscow: Geological Institute Press, pp. 171-179. (in Russian) 
Larochkina IA, Silantiev VV (2007) (eds.) Geologicheskie pamiatniki prirody Respubliki Tatarstan [Geological heritage of Tatarstan Republic]. Akvarel, Kazan, Russian Federation. (in Russian)

Leonova TB (2007) Correlation of the Kazanian of the Volga-Urals with the Roadian of the global Permian scale. Palaeoworld 16:246-253.

Makarova OV (2007) Miospores. In: Larochkina IA, Silantiev VV (eds.) Geologicheskie pamiatniki prirody Respubliki Tatarstan [Geological heritage of Tatarstan Republic]. Akvarel, Kazan, Russian Federation, pp. 82-83. (in Russian)

Mangerud G (1994) Palynostratigraphy of the Permian and lowermost Triassic succession, Finnmark Platform, Barents Sea. Review of Palaeobotany and Palynology 82:317-349.

Molin VA, Koloda NA (1972) Upper Permian spore and pollen assemblages of the north of the Russian platform. Nauka, Leningrad, 76 p. (in Russian)

Ruckwied K, Götz AE, Jones P (2014) Palynological records of the Permian Ecca Group (South Africa): Utilizing climatic icehouse-greenhouse signals for cross basin correlations. Palaeogeography, Palaeoclimatology, Palaeoecology. http://dx.doi.org/10.1016/j.palaeo.2014.05.003.

Ruckwied K, Götz AE, Pálfy J, Török Á (2008) Palynology of a terrestrial coal-bearing series across the Triassic/Jurassic boundary (Mecsek Mts., Hungary). Central European Geology 51(1):1-15.

Shen SZ, Schneider JW, Angiolini L, Henderson CM (2013) The International Permian Timescale: March 2013 update. In: Lucas SG, DiMichele W, Barrick JE, Schneider JW, Spielmann JA (eds) The Carboniferous-Permian Transition. New Mexico Museum of Natural History and Science, Bulletin 60:411-416.

Silantiev VV (2001) The organic world of Kazan Ages on the East European platform. In: The Evolution of the Organic World. Evolution of Biota. Tomsk University Press, Tomsk, Russia, pp. 732-737. (in Russian) 
Solodukho MG, Gusev AK, Ignatyev VI et al. (1993) Permian system: guides to geological excursions in the Uralian type localities. Part 5. Volga Region. Occasional Publications, Earth Sciences and Resources Institute, New Series 10:269-303.

Stratigraphic Code of Russia (2006) The third edition, VSEGEI, St. Petersburg, Russia, 96 p. (in Russian)

Utting J, Esaulova NK, Silantiev VV, Makarova OV (1997) Late Permian palynomorph assemblages from Ufimian and Kazanian type sequences in Russia, and comparison with Roadian and Wordian assemblages from the Canadian Arctic. Can J Earth Sci 34:1-16.

Varyukhina LM (1971) The spores and pollen of red-coloured and coal bearing deposits of the Permian and Triassic in the northeast part of Russia. Academy of Sciences, USSR, Komi Branch, Institute of Geology, Nauka, Leningrad, USSR, 159 p. (in Russian)

Varyukhina LM, Koloda NA, Molin VA, Fefilova LA, Chalyshev VI (1975) Biogeographical zonation of the European North of the USSR (Permian and Triassic). Nauka, Leningrad, USSR, pp. 100-229. (in Russian)

Virbitskas AB (1983) Miospores. In: Meyen, S.V. (ed.) Paleontological atlas of Permian deposits from the Pechora coal basin. Nauka, Leningrad, USSR, pp. 93-201. (in Russian)

Ziegler AM, Hulver ML, Rowley DB (1997) Permian world topography and climate. In: Late glacial and postglacial environmental changes: Pleistocene, Carboniferous-Permian, and Proterozoic. Oxford University Press, Oxford: pp. 111-146. 